\title{
Samhørighed, interaktion og vidensdeling blandt studerende - erfaringer fra et IKT-pædagogisk udviklingsprojekt
}

Jacob Davidsen, adjunkt, Institut for Kommunikation, Aalborg Universitet

Thomas Ryberg, professor (mso), Institut for Kommunikation, Aalborg Universitet

\section{Reviewet artikel}

I artiklen beskriver vi erfaringer fra et projekt på Aalborg Universitet (AAU), hvor forfatterne designede et forløb med Google+ communities for at skabe øget samhørighed, interaktion og vidensdeling mellem studerende på 1. semester på studiet Kommunikation og Digitale Medier (KDM). Studier viser, at studerende i vid udstraekning anvender sociale netvorkssteder, såsom Facebook, i forbindelse med deres studieliv til faglige, men i saerdeleshed sociale aktiviteter. Det betyder, at vi som undervisere har et begraenset indblik i, hvad de studerende kommunikerer om og har af problemstillinger i deres studieliv, hvilket er problematisk i forhold til at udvikle et fagligt faellesskab og forankringspunkt. Det skyldes endvidere, at brugen af det institutionelle system Moodle er begranset til envejskommunikation fra underviser til studerende. Formålet med udviklingsprojektet var således at skabe et tredje rum imellem Facebook og Moodle, som skulle give de studerende oplevelser og erfaringer med, hvordan de kan bruge og finde inspiration i hinandens arbejde ved at deltage i et online-foellesskab sammen med underviserne. Projektet viser, at underviserne spiller en central rolle i udviklingen af online-fallesskabet, men samtidig, at nogle af forløbets aktiviteter har haft positiv indflydelse på de studerendes samhørighed, interaktion og vidensdeling gennem forløbet.

\section{Indledning}

At starte på en videregående uddannelse er en hektisk periode med mange nye indtryk, personligt, fagligt og socialt. I løbet af det første år skal nye studerende lære hinanden at kende, mestre den akademiske arbejdsform samt udvikle en faglig identitet. De studerende skal lære et nyt sprog - mundtligt og skriftligt - så de kan deltage i diskussioner inden for deres felt, give konstruktiv kritik til deres medstuderende og formidle komplekse problemstillinger i opgaver og projekter (Rienecker, Von Müllen, Stray Jørgensen \& Holten Ingerslev, 2012). Dertil kommer, at studerende på Aalborg Universitet (AAU) skal lære en ny praksis i form af det projekt- og problemorienterede projektarbejde. I denne artikel præsenterer, analyserer og diskuterer vi et IKT-pædagogisk udviklingsprojekt fra 1. semester på Kommunikation og Digitale Medier (KDM), AAU. Det overordnede formål med udviklingsprojektet var at skabe et stærkere kollektivt læringsmiljø på semestret og give de studerende en stærkere 
forståelse af, at de kan (og bør) være ressourcer for hinanden. I projektgrupperne er der typisk et stærkt samarbejde, men vores ønske var at benytte et Google+ community (herefter blot Google+) til at skabe en stærkere faglig og social vidensdelingskultur blandt de studerende på årgangen samt at skabe et fællesfagligt rum for både underviserne og de studerende. Vores mål var at skabe dette ved at støtte samhørighed, interaktion og vidensdeling. Samhørighed forstår vi som den fundamentale idé, at de studerende føler, de tilhører et basalt fælleskab; at de er sammen om at være 1. semesters-studerende på KDM, og at de kan bruge hinanden. Interaktion er de løbende udvekslinger, der skal understøttes for at bibeholde forestillingen om, at man er sammen om noget. Vidensdeling er det tredje led, hvor interaktionerne antager en faglig dimension.

I artiklen gennemgår vi kort nogle kendetegn ved uddannelsen, som har betydning for udformningen af forløbet og aktiviteterne omkring Google+. Dernæst præsenteres opsætningen af Google+, hvorefter pædagogik, aktiviteter og undervisers rolle beskrives. Herefter analyseres de studerendes oplevelse af forløbet og aktiviteterne baseret på en spørgeskemaundersøgelse, to fokusgruppeinterviews og data fra Google+. Sluttelig diskuterer vi potentialer og udfordringer ved at facilitere onlinefællesskab på de videregående uddannelser og kommer med bud på, hvordan sådanne IKT-pædagogiske udviklingsprojekter kan forankres i organisationen.

\section{PBL, IKT og gruppernes relationer på 1. semester}

Udviklingsprojektet er forankret i et allerede eksisterende kursus om Problem Baseret Læring (PBL) på 1. semester, KDM, hvor ca. 85 studerende startede i 2015. Kurset har til formål at introducere de studerende for det problemorienterede projektarbejde (PBL) som det praktiseres på AAU. Kurset forløber over 12 kursusgange og introducerer de studerende til PBL, problemformulering, gruppedynamikker mv. De enkelte fakulteter/uddannelser på AAU forholder sig selvstændigt til introduktionen af PBL, men de fleste uddannelser baseres på disse grundlæggende principper for AAU-PBL (Askehave, Linnemann Prehn, Pedersen \& Thorsø Pedersen, 2016):

- Problemet som udgangspunkt

- Projektorganisering i grupper

- Projektet understøttes af kurser

- Samarbejde - grupper, vejleder, eksterne parter

- Eksemplaritet

- Ansvar for egen læring.

Principperne udgør en overordnet tilgang til problembaseret læring på AAU. For at støtte de studerendes læring af PBL-principperne anvender flere uddannelser såkaldte P0-projekter på 1. semester, hvor de studerende i sammensatte grupper skal arbejde med en problemstilling defineret af underviserne. De studerende får på den 
måde et forsøg med PBL under vejledning fra underviserne, hvor de bliver bekendte med PBL, og hvordan det er at arbejde sammen i grupper. Senere skal de studerende selv danne grupper og formulere et problem inden for semestrets temaramme.

Udover P0-projektet følger de studerende på KDM et 5 ECTS-forløb om PBL. Dette modul skal fungere som afsæt for det problem- og projektorienterede arbejde op gennem uddannelsen. Det er dette forløb, vi gennem brugen af Google+ har forsøgt at re-designe, så de studerende i højere grad får akademisk praksis og PBLprincipper ind under huden gennem aflevering af refleksionsopgaver samt for at skabe samhørighed, interaktion og vidensdeling mellem hinanden og med undervisere i et online-fællesskab.

\section{IKT på studiet}

AAU anvender Learning Management Systemet (LMS) Moodle til administration af kurser og kun i mindre grad til interaktion mellem de studerende. Gennem de seneste 6 år har uddannelsen brugt Moodle som platform til administration af kurser og håndtering af indhold. Dog er Moodle mestendels blevet anvendt som en silo til slides og til beskeder fra underviser til studerende (Bygholm \& Nyvang, 2013). Tidligere har undervisere på uddannelsen forsøgt at anvende online-fællesskaber i form af platformene Elgg og Mahara (Ryberg \& Wentzer, 2011) for at understøtte de studerendes arbejde i grupper, portfolioskrivning og faglige identitetsdannelse. Mahara findes stadig som system på AAU, men lever en lidt tilbagetrukket tilværelse, hvor det ikke bliver stærkt internt promoveret. De studerende sammensætter og komponerer derfor typisk egne løsninger til at understøtte projektarbejdet (Ryberg, Davidsen \& Hodgson, 2016; Thomsen, Sørensen \& Ryberg, 2016). De nye studerende på KDM gennemgår dog et undervisningsforløb designet af 5 . semesters studerende i IKT-relevante PBL-værktøjer (Konnerup \& Dirckinck-Holmfeld, 2016).

En af grundene til at anvende Google+ er, at det sammenlignet med Moodle minder mere om de sociale medier, de studerende anvender i deres hverdag. En type studier viser, at studerende på de videregående uddannelser i vid udstrækning anvender Facebook til kommunikation og koordinering i deres projektgruppe (Thomsen, Sørensen \& Ryberg, 2016) og til intern kommunikation blandt de studerende på de respektive semestre (Madge, Meek, Wellens \& Hooley, 2009). Sidstnævnte konkluderer endvidere, at undervisere skal være påpasselige med ikke at blande de studerendes uformelle sociale rum med mere formelle læringsaktiviteter. Dette kan dels generere støj i de studerendes uformelle rum men også i relation til Facebook betyde, at kombinationen af sociale forbindelser og algoritmiske processer influerer på, hvem der ser hvad fra hvem (Nicolajsen \& Ryberg, 2014). En anden type studier eksperimenterer med at anvende Facebook som platform for læringsfælleskaber for at hjælpe nye studerende med at forstå akademisk kodeks og for at etablere studiegrupper støttet af en tutor (Cuesta, Eklund, Rydin \& Witt, 2016). Forfatterne viser po- 
sitive tendenser i de studerendes forståelse af akademisk kodeks, og at tutoren har en vigtig rolle i forhold til at etablere en åben atmosfære i gruppen på 24 studerende. Brugen af mere genkendelige systemer, som Twitter, Facebook og Google Drive tilbyder ifølge Thoms (2015) bedre muligheder for at understøtte praksisfællesskaber, videnskonstruktion og læring sammenlignet med de institutionelle systemer. Hertil vil vi dog tilføje, at man også kan benytte Moodle til dette, men der er nogle arkitektoniske og interfacemæssige fordele ved Google+. For eksempel, at Google+ er en flad opslagstavle, hvor deltagerne hurtigt og umiddelbart kan poste multimodalt indhold. Vi ønskede med vores design og brug af Google+ at skabe et tredje rum, som eksisterede imellem studiets faglige og formelle brug af Moodle og så de studerendes egen brug af Facebook til social koordination og udveksling. Vi var velvidende om, at de studerende parallelt med forløbet på Google+ ville benytte sig af en semestergruppe på Facebook.

Endelig var det også et mål, at Google+ måske kunne komme til at fungere som en årgangsportfolio eller digital forankring for de studerende. Moodle er opdelt i semestre, og derfor mangler de studerende en form for historie gennem bachelorforløbet. De studerende kan vende tilbage til et tidligere semesterrum i Moodle, men der mangler en samlet årgangsportfolio, hvor alle materialer, interaktioner og opgaver findes. Vi håbede Google+ kunne blive et sådant digitalt forankringspunkt.

\section{Gruppernes indbyrdes relation}

Vores erfaring med projektgrupper er, at de ofte lukker sig om sig selv, når det egentlige projektarbejde starter (Ryberg \& Wentzer, 2011; Dirckinck-Holmfeld, 2016). Dette blev også tilfældet, selvom flere af grupperne arbejdede med samme emne. I et nyere studie (Ryberg, Davidsen \& Hodgson, 2016) er det også blevet tydeligt, at de studerende på KDM lever et nomadisk liv, hvor de ikke har faste gruppepladser og dermed mindre mulighed for uformelt at udveksle med de andre studerende. Hommes et al. (2012) har gennem en statistisk undersøgelse af tre sociale netværk med i alt 301 førsteårs-medicinstuderende fra Maastricht University kortlagt, at social interaktion mellem studerende inden for og uden for de institutionelle rammer har stor betydning for de studerendes læringsudbytte på uddannelsen. Rienties, Carbonell, Alcott og Willis, (2012) påpeger endvidere, at vidensdeling over tid veksler mellem at finde sted internt i gruppen og eksternt i relationerne til andre grupper. Derfor er det interessant at eksperimentere med IKT som middel til at støtte samhørighed, interaktion og vidensdeling mellem grupperne tidligt på uddannelsen, så der udvikles en kultur og praksis herfor.

\section{Google+ kort fortalt}

Google+ er et gratis, webbaseret online-forum. Udover web, er der applikationer til smartphones og tablets. Det enkelte community kan gøres privat, så kun inviterede brugere kan deltage. Brugerne kan lave traditionelle tekstbaserede indlæg, men og- 
så indlæg med videoer og billeder samt mindre meningsmålinger. Dertil kommer, at brugerne nemt kan dele dokumenter fra Google Docs i Google+. Systemet understøtter således multimodale kommunikationsformer, hvilket giver mere frihed for den enkelte til at udtrykke sig. Google+ har en "synes godt om"-knap i form af et "+1" som brugerne kan anvende for at vise, at de synes om indlægget eller har set det. Dette har karakter af hverdagskommunikation, men det er også en måde at vise tilstedeværelse og samhørighed på i online-fællesskabet, uden at man nødvendigvis behøver at skrive et indlæg/kommentar. I modsætning til traditionelle fora samles alle indlæggene i Google+ i en fælles strøm af beskeder. Strømmen af beskeder kan blive uoverskuelig i takt med, at mængden af indlæg stiger, men ved at klikke på den enkelte kategori eller et hashtag sorteres de.

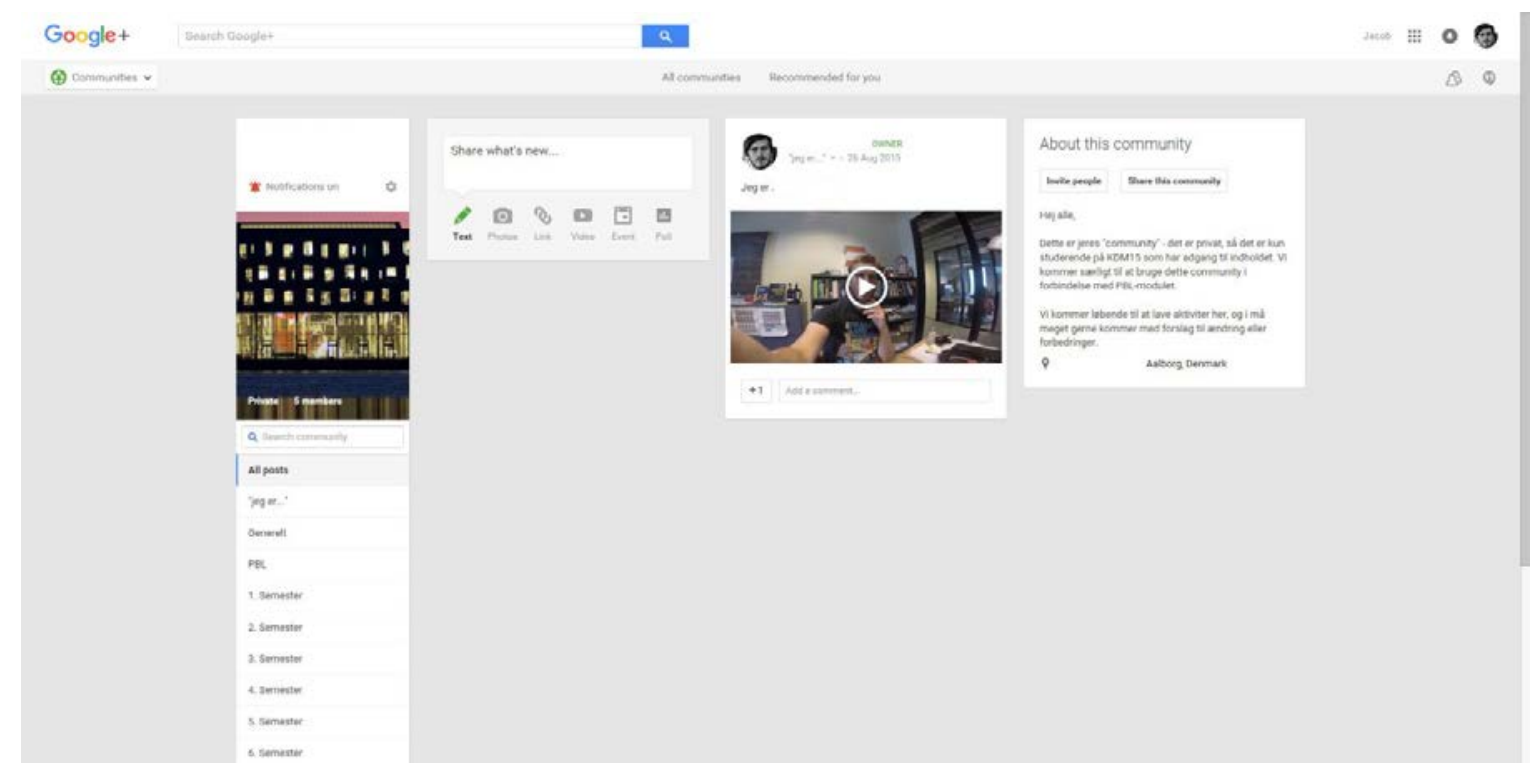

Figur 1. Screenshot af Google+.

Vi havde forestillet os, at hver gruppe skulle have deres eget rum i form af en kategori, men på nuværende tidspunkt understøtter Google+ kun oprettelsen af 20 kategorier og derfor besluttede vi, at de studerende skulle "tagge" deres afleveringer med gruppenummer \#P0-1 og opgavens titel \#samarbejdeogarbejdsdeling, så de efterfølgende kan vende tilbage til deres afleveringer senere på studiet. Den endelige opsætning af Google+ blev forholdsvis simpel med kategorier til:

- $\quad$ hvert semester (for at vise det langsigtede forløb)

- videopræsentation af de studerende og undervisere

- generelle beskeder fra undervisere

- PBL-forløbet

- afleveringer

- deling af værktøjer og ressourcer

- de studerendes råd på årgangen (blev oprettet senere) 
For at skabe rum og mulighed for samhørighed, interaktion og vidensdeling besluttede vi, at alle opgaver skulle afleveres offentligt, så medstuderende havde mulighed for at læse og kommentere bidraget. Aflevering i et frit forum rummer både udfordringer og potentialer - de studerende kan på den ene side føle ubehag og usikkerhed omkring deres faglighed og præstation, men på den anden side kan det virke motiverende, at andre kan læse ens opgave. Flere af opgaverne var baseret på skabeloner fra Holgaard, Ryberg, Stegeager, Stentoft og Thomassen (2014), eksempelvis skabelon til forventningsafstemning og problemanalyse, så de studerende havde et bedre og fælles udgangspunkt for at besvare opgaverne.

\section{Pædagogik og undervisers rolle i forløbet}

Overordnet forsøger vi at uddanne de studerende til at være opmærksomme på hinanden gennem en række opgaver og aktiviteter i Google+, hvor de bliver positioneret som aktive medskabere af et fagligt fællesskab. Google+ skal ses i sammenhæng med traditionelle undervisningsformer: forelæsninger, øvelser, opgaver og workshops. Det er således en form for hybridt undervisnings- og læringsrum, vi søger at etablere sammen med de studerende gennem øvelser i undervisningslokalet og aktiviteter på Google+. I den tidlige forskning om PBL beskrev Illeris (1974, s, 121) at

"Indloringen foregår (...) gennem et stadigt samspil mellem individet og dets omgivelser, og karakteren af disse omgivelser - fysiske såvel som sociale - bliver dermed afgørende for indloeringsmulighederne."

Dette har vi søgt at realisere gennem at skabe en rutine og faglig praksis blandt de studerende, hvor det bliver naturligt at dele og vise hinanden noter, tekster, produkter og øvelser på tværs af semestergrupperne. Grundlæggende var målet, at de studerende udviklede en forståelse af, at de kan lære sammen ved at dele og finde inspiration i hinandens arbejde. Dette har vi søgt at understøtte gennem et fokus på samhørighed, interaktion og vidensdeling. De tre begreber er inspireret af Wengers (1998) teori om praksisfælleskaber, hvor samhørighed minder om hvad Wenger kalder 'joint enterprise', interaktion om 'mutual engagement' og vidensdeling om 'shared repertoire', uden de dog er identiske. Vi forstår samhørighed, som en vigtig grundsten i fællesskabet på uddannelsen, hvor de studerende bliver opmærksomme på hinanden som deltagere. Selvom det kan lyde banalt, behøver fællesskabet ikke være til stede. De studerende kunne blot komme til forelæsningerne og kun have gruppearbejdet til fælles. Vores mål var, at de skulle få erfaringer og oplevelser med, hvordan årgangen kan fungere som kontekst for både deres individuelle og gruppebaserede aktiviteter. Fornemmelsen af samhørighed skal understøttes gennem løbende interaktion, som dækker alt fra spørgsmål og kommentarer til +1 på Google+, mellem de studerende og mellem studerende og undervisere. Interaktion omfatter dels ren social kommunikation, som er en vigtig del af at skabe og vedligeholde 
samhørigheden, dels interaktion om opgaver, ressourcer og faglige spørgsmål. Slutmålet er, at der skal opstå vidensdeling, hvor de studerende begynder at finde inspiration i hinandens arbejde, udfordrer hinanden og deler faglige ressourcer for at skabe et fælles vidensgrundlag og handlerum. Dette forudsætter dog, at der er opbygget et basalt socialt fællesskab, hvor der eksisterer tillid og tryghed i forhold til det at dele (Salmon, 2002).

Med introduktionen af Google+ som en del af undervisningsrummet skifter underviser endvidere mellem forskellige roller afhængig af tid, kontekst og relationer. Overordnet forsøgte vi at strukturere de studerendes adgang til og behandling af viden, deltagelse i fællesskabet og praksis, så de blev aktive deltagere og ikke blot betragtere. Belært af tidligere erfaringer med Elgg og Mahara (Ryberg \& Wentzer, 2011) designede vi en række obligatoriske opgaver, da det viste sig, at frivillige aktiviteter ikke understøtter udviklingen af et fagligt fællesskab. Så for at kultivere og facilitere samhørighed, interaktion og vidensdeling mellem de studerende designede vi forskellige opgaver til de studerende, som blev afleveret i Google+:

- Personlig introduktion i form af en 15 sekunders video.

- Mindre opgaver i forbindelse med undervisningen - eksempelvis "hvad er forskellen på arbejdsdeling og samarbejde? - find to billeder, som repræsenterer de to arbejdsformer og skriv en kort kommentar om forskellene".

- Fem opgaver, som de studerende afløser i deres P0 eller P1 grupper med udgangspunkt i temaer fra undervisningen.

- Mindre meningsmålinger - eksempelvis “Hvilken ungdomsuddannelse kommer du fra?"

Vi producerede selv små præsentationsvideoer til de studerende for at vise forventninger til formatet. Nogle studerende valgte at lave små kreative kortfilm, mens andre lavede helt traditionelle videoer. Dette var den eneste individuelle opgave (nogle af de studerende gik dog sammen for at lave videoen). Efterfølgende afleverede de studerende opgaverne i deres grupper. Vi kommenterede i vid udstrækning de studerendes indlæg i form af spørgsmål, og særligt sørgede vi for at kommentere kort på de opgaver, grupperne delte i Google+. De studerende skrev også indlæg og kommenterede hinandens indlæg, men vi nåede ikke helt frem til et stadie, hvor de studerende konsekvent kommenterede fagligt på hinandens opgaver i det offentlige Google+ rum.

\section{Analyse - de studerendes oplevelser med Google+}

Grundlaget for analysen bygger på et spørgeskema (55 ud af 72 studerende svarede), to fokusgruppeinterviews med henholdsvis fire og fem studerende fra årgangen samt den løbende interaktion på Google+. Analysen har tre temaer: frekvensen af besøg på Google+, forholdet mellem Moodle, Google+ og Facebook og inspiration og 
vidensdeling mellem de studerende på Google+. Dette leder over i en diskussion af udfordringer og potentialer ved at anvende Google+ som platform for facilitering af samhørighed, interaktion og vidensdeling.

\section{Frekvensen af besøg}

Antallet af besøg på Google+ varierer mellem flere daglige besøg (13\%), en gang om dagen (33\%), et par gange om ugen (45\%) og et par gange siden de studerende startede på universitetet (9\%) (Diagram 1). Størstedelen af de studerende besøger online-fællesskabet et par gange om ugen, hvilket indikerer, at de studerende finder onlinefællesskabet relevant for deres studie, men det fortæller ikke noget om de studerendes interaktion med indholdet eller hinanden.

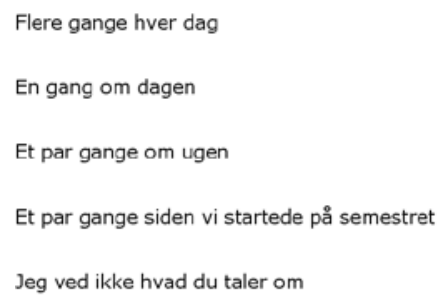

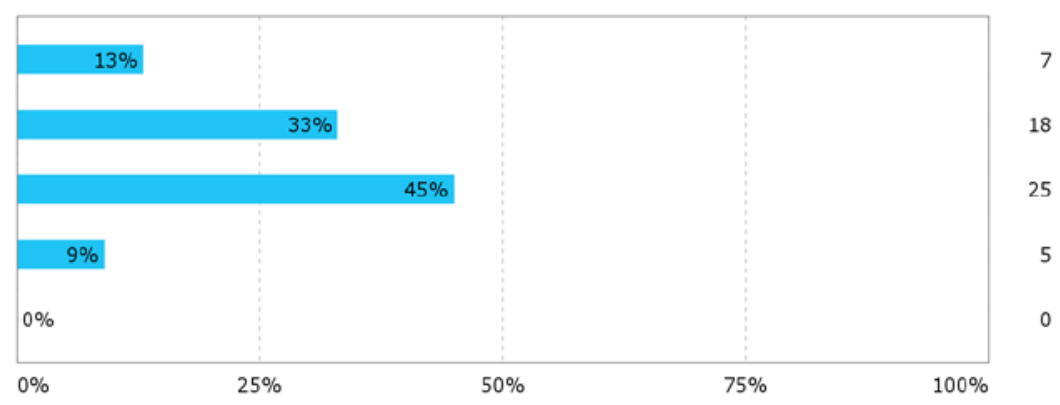

Diagram 1 - Hvor ofte har du besøgt Google +?

Baseret på statistik fra Google+ kan vi endvidere se, at de studerendes aktivitet (indlæg og +1) bølger op og ned i takt med kursusaktiviteter såsom upload af opgaver og øvelser i forbindelse med undervisningen. Vi ser altså, at de studerende til en vis grad er afhængige af, at underviser tilrettelægger aktiviteter og forløb, de kan deltage i. Den spontane, offentlige og faglige interaktion skal således faciliteres, og vi valgte til en start at gøre dette gennem obligatoriske opgaver. Selvom vi opfordrede de studerende til at stille spørgsmål åbent, så var der stadig nogle, som skrev private beskeder til underviser om spørgsmål med relevans for hele årgangen. Vi valgte at besvare spørgsmålene offentligt i Google+ for at gøre vores svar tilgængelige for hele årgangen samt tilskynde til en åben kultur for vidensdeling på studiet.

\section{Forholdet mellem Moodle, Google + og Facebook}

Fra studiets side forventes det, at de studerende anvender Moodle og Google+, mens de studerende selv ibrugtager andre sociale netværkstjenester såsom Facebook, Dropbox eller Google Drive. Derfor er det også positivt, at 56\% af de studerende indikerer, at Moodle havde størst faglig betydning, efterfulgt af Google+ med 33\% (Diagram 2). Derudover indikerer 10\% af de studerende, at andre tjenester har haft størst faglig betydning. 


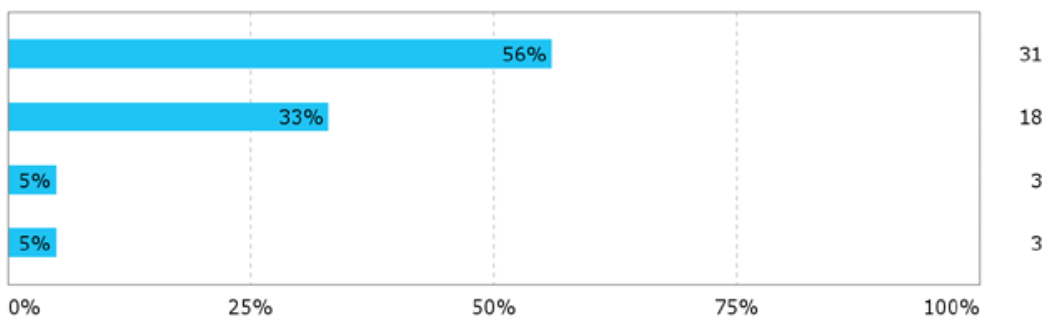

Diagram 2 - Hvilket forum har haft størst faglig betydning på semestret?

Selvom tallene viser, at de studerende tilskriver Moodle størst faglig betydning, så forklarer flere af de studerende under fokusgruppeinterviewene relationen mellem teknologierne på en anden måde. Flere af de studerende rangerer teknologier i følgende rækkefølge 1. Facebook, 2. Google+ og 3. Moodle, som illustreret i nedenstående tegning fra et af fokusgruppeinterviewene.

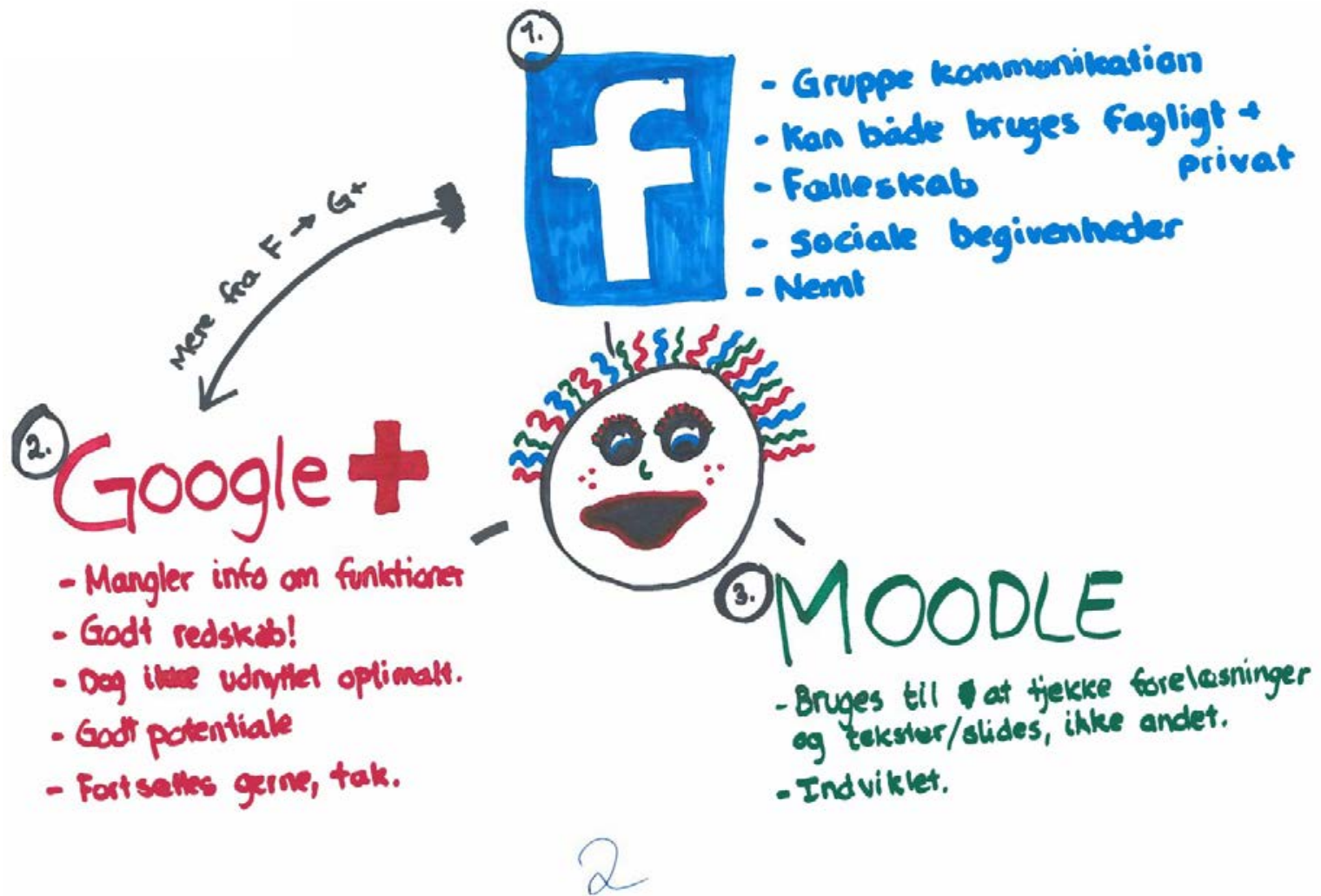

Figur 2 - Tegning af forholdet mellem Moodle, Facebook og Google+.

Selvom de studerende vurderer, at Moodle har størst faglig betydning, så er det interessant, at Moodle primært anvendes til at "tjekke forelæsning og tekster/slides, ikke andet", hvorimod Google+ og Facebook i højere grad støtter fællesskab og interaktion set fra de studerendes perspektiv. Dette var også tydeligt i en undersøgelse af 5. semesters-studerende ved samme uddannelse (Thomsen, Sørensen og Ryberg, 2016). Ligeledes viser resultaterne fra Petrovic, Jeremic, Cirovic, Radojicic og Milenkovic' (2013)'s studie af forholdet mellem Facebook og Moodle, at de studerende ikke foretrækker den ene eller den anden platform, men derimod en kombination. Tegningen illustrerer endvidere at Google+ rummer et potentiale, men at Facebook i 
højere grad støtter de studerendes fællesskab - særligt den sociale del. En studerende giver udtryk for, at en grundigere introduktion til Google+ kunne have ændret brugen af teknologien:

"Jeg tror, at det kunne have hjulpet en hel del, hvis vi havde haft et eller andet lille kursus i starten for at blive bedre til at bruge det her Google+. For eksempel havde jeg lidt svoert ved at navigere rundt, det var lidt uoverskueligt, hvordan det lige hang sammen."

Selvom generationen af studerende ofte bliver skildret som digitalt indfødte, så peger både litteraturen og tidligere erfaringer på, at der er brug for introduktion og stilladsering (Heilesen \& Davidsen, 2016; Ryberg \& Wentzer, 2016). Det mente vi også, vi gjorde, men der er øjensynligt behov for stærkere introduktion. Videoaktiviteten, som var tænkt som en lille opvarmningsopgave, blev heller ikke modtaget udelukkende positivt af alle studerende. Nogle udtrykte bekymring ved at skulle lave en introduktionsvideo og "lægge sig selv op". Dette kan måske undre, når man tænker på, hvor udbredt Instagram, Facebook og Snapchat er, men det bør minde os om, at studiestart er en social situation, hvor der er meget på spil. At vi som undervisere bruger medier, der benyttes til uformel social udveksling, gør ikke situationen uformel eller medfører, at der ikke er noget på spil for de studerende. Dette var også med i vores overvejelser omkring videoen. Derfor fik de studerende lov til at lave dem sammen, og de, der virkelig ikke havde lyst, tvang vi ikke. Aktiviteten afstedkom en stor mængde af gode og sjove videoer, og da aktiviteten først gik i gang, lod det også til at reservationerne forsvandt for de fleste (i alt blev der uploadet 53 videoer).

\section{Inspiration og vidensdeling mellem de studerende}

De studerende indikerer, at de i meget høj grad (13\%), i høj grad (40\%), i nogen grad (33\%), i mindre grad (11\%) og slet ikke (4\%) er blevet inspireret af eller har reflekteret over egne opgaver baseret på de andre gruppers opgaver (Diagram 3).

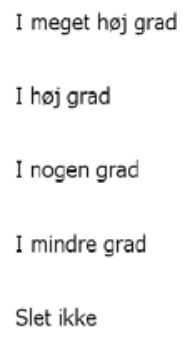

Diagram 3 - I hvilken grad har andre gruppers opgaver givet anledning til inspiration og refleksion?

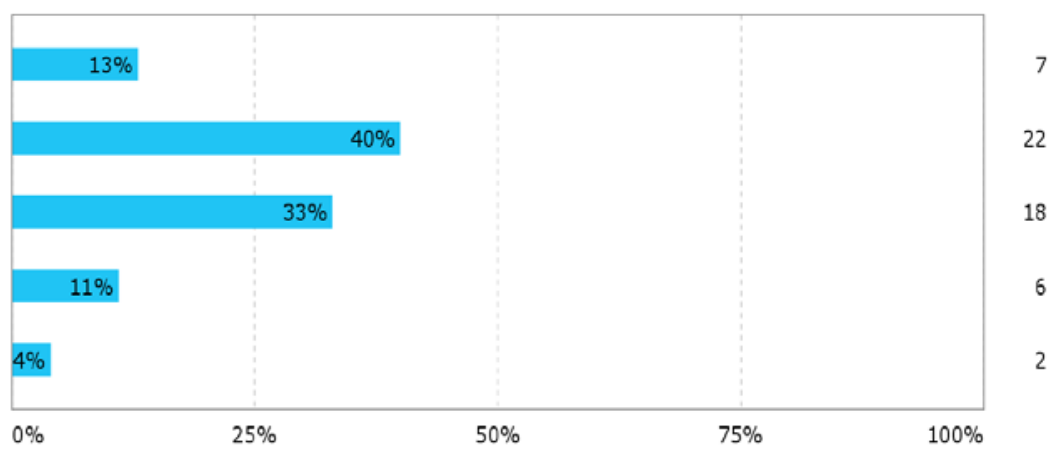
. 
Det er positivt, at størstedelen af de studerende indikerer, at andre gruppers opgaver har givet anledning til inspiration og refleksion, hvilket antyder, at de offentlige afleveringer har haft betydning for de enkelte gruppers arbejde. En af de studerende forklarer, hvordan de har brugt andres opgaver som inspiration for deres eget arbejde:

"Vi har så gjort sådan, at når vi har vœeret foerdige, så har vi kigget på andres (indloeg/opgaver) for at se om det er det samme, vi er nået fem til eller sådan, er vi enige og så diskutere det. Hvorfor gør vi det, hvorfor gør de det. Det har vaeret en god måde lige at kunne have noget, at veje sig op imod og så have et diskussionspunkt i."

De studerende bruger altså hinandens opgavebesvarelser som genstand for diskussion og refleksion over eget arbejde med opgaverne. I forhold til andre gruppers indflydelse på gruppens aktivitet på Google+ indikerer 58\%, at de i høj (42\%) eller meget høj grad (16\%) er blevet påvirket af andre gruppers indlæg eller spørgsmål. $40 \%$ af de studerende indikerer, at de i nogen (31\%) eller mindre grad (9\%) er blevet påvirket af de andre grupper (Diagram 4). Endelig har 2\% indikeret, at de andre gruppers aktivitet ingen betydning havde for deres egen.
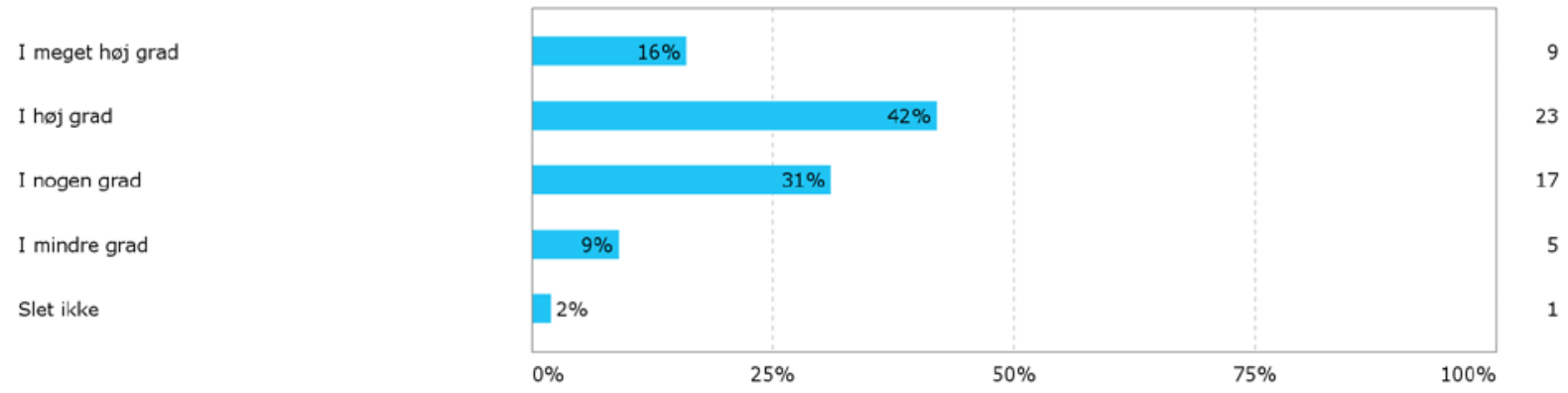

Diagram 4 - I hvor høj grad har andre gruppers indlaeg/spørgsmål haft indflydelse på din gruppes aktivitet på Google +?

Selvom svarprocenterne viser en forholdsvis positiv tendens i forhold til de studerendes deltagelse i online-fællesskabet, så understreger følgende fortælling fra en af de studerende en vis ambivalens i forhold til det at dele sit arbejde; noget som dog har forandret sig i takt med forløbets udvikling:

"Hvorfor skulle jeg loegge det derud, hvis der så ikke er nogle, der bruger det eller måske nogle, der giver negativ feedback på det, eller det kommer jo lidt an på, hvad man vil bruge det til, toenker jeg. Men jeg har brugt det meget, jeg har loest en del af, hvad de andre har skrevet. Jeg synes, at det er en af de største forandringer ved at gå herude kontra hvad man ellers har prøvet. Det er det der med, at man er mere villig til at dele." 
Den studerende har ændret holdning til at dele opgaver offentligt gennem forløbet fra en indledende skepsis til en åbenhed og villighed til at dele. En anden studerende påpeger et andet positiv aspekt i forhold til deling, nemlig at "man ikke bare sidder i sin egen lille boble med sit word-dokument". Det indikerer, at de studerende har ændret attitude til det at dele og være en del af et online-fællesskab gennem deltagelsen på Google+.

\section{Diskussion og konklusion}

Formålet med det IKT-pædagogiske udviklingsprojekt var at skabe en stærkere kollektiv bevidsthed på semestret om, at de studerende kan og skal være ressourcer for hinanden. Selvom der er stærkt samarbejde i projektgrupperne, så var vores ønske at benytte Google+ fællesskabet til at skabe en stærkere faglig og social vidensdelingskultur samt et fællesfagligt rum for både underviserne og de studerende. Dette ved at skabe et digitalt rum, der eksisterer imellem de studerendes Facebookgrupper og så det institutionelle system: Moodle. Målet var at skabe dette ved at støtte samhørighed, interaktion og vidensdeling. Erfaringerne fra det IKTpædagogiske udviklingsprojekt viser, at det er muligt at skabe et fælles rum, der kan støtte udvikling af samhørighed, interaktion og vidensdeling. Vi kan se ud fraaf spørgeskemaet og analysen af deltagelse i Google+, at de studerende har været forholdsvis aktive og opsøgende i forhold til - dog særligt omkring de aktiviteter, vi som undervisere har igangsat. Det nævnes tillige i interviews og poster som et rum, som de studerende gerne vil beholde. Det er i vores øjne et meget positivt resultat, at de studerende faktisk har fundet inspiration i hinandens afleveringer. Dette har ikke været manifest i selve forløbet, da de sjældent har kommenteret direkte på hinandens arbejde. Dette vil vi arbejde videre med, da vi planlægger, at de kommende studerende skal give hinanden peer-feedback på opgaverne, I denne forbindelse vil vi arbejde med rammer for konstruktiv kritik.

Vi mener også, at det delvis er lykkedes at skabe et tredje rum for fællesfaglig diskussion, der eksisterer mellem det institutionelle LMS og så de studerendes selvdrevne Facebook-grupper. Google+-fællesskabet har nogle arkitektoniske og interfacemæssige fordele, som ikke ligger i Moodle, og det ligger - på systemniveau - genremæssigt tættere på de sociale medier, der benyttes i de private og selvdrevne aktiviteter for de studerende. Samtidigt er det vigtigt at understrege, at der er brug for introduktion og understøttelse fra undervisernes side, ligesom det er vigtigt at erkende, at et rum ikke bliver uformelt, a-hierarkisk og kollegialt af, at man adopterer teknologier, der bruges i uformelle sammenhænge. Vi som undervisere må huske på og erkende, at selvom vi ikke har noget på spil i situationen, så har de studerende "noget på spil" - både i forhold til hinanden og i forhold til os. Det betyder også, at det for de studerende er et angstprovokerende vovestykke at skulle dele fagligt arbejde med hinanden og lave videointroduktioner på semesterniveau. Men det er et spring, vi må insistere på, at de tager. 
Der er dog også nogle udfordringer. Det er tydeligt, at skabelsen og vedligeholdelsen af et digitalt fagligt fællesrum er meget afhængigt af undervisernes engagement og tilrettelæggelse af rum og aktiviteter. Til eksempel kan vi konkludere, at idéen om at skabe en årgangsportfolio og et fællesfagligt rum, som følger de studerende gennem deres bacheloruddannelse, kan blive vanskelig at realisere, da de studerende ikke selv tager teten i forhold til at skabe online-fællesskab på Google+. Som en af de studerende fortæller, så afhænger deres fremtidige brug og deltagelse af underviserne på de næste semestre:

"Det kommer helt an på dem (underviserne, red. forfatterne), hvis de ikke bruger det, så bruger vi det heller ikke. Men hvis de bruger det og siger det er dér, vi skal afvikle et nyt fag i gennem eller et eller andet, så bruger vi det."

De studerende bruger fortsat Facebook til kommunikation om studiet, hvilket underviserne dog ikke har adgang til at se. De studerende har behov for et privat rum uden undervisernes tilstedeværelse, og her foregår faglig sparring og udveksling. Dog ikke helt på niveau med at lægge opgaver ud og kommentere på hinandens faglige produkter (Thomsen, Sørensen \& Ryberg, 2016). Der ligger altså en større udfordring i løbende at understøtte denne kultur og type af vidensdeling mellem de studerende samt i at bibeholde et fællesfagligt rum. Vi kan også håbe på, at der i dette udviklingsprojekt er blevet sået frø til en kultur, hvor de selv tager yderligere initiativ til at understøtte semesterbaseret samhørighed, interaktion og vidensdeling.

Jacob Davidsen er adjunkt ved Institut for Kommunikation på Aalborg Universitet. Han er tilknyttet forskningscenteret e-Learning Lab - Center for Brugerdrevet Innovation, Loering og Design. Han er saerligt interesseret i samspillet mellem IT og laering, samt hvordan laering og laereprocesser kan studeres og synliggøres gennem videobaserede multimodale interaktionsanalyser.

Thomas Ryberg er professor (mso) ved Institut for Kommunikation på Aalborg Universitet. Han er tilknyttet forskningscenteret e-Learning Lab - Center for Brugerdrevet Innovation, Laering og Design. Han er specielt interesseret $i$, hvordan nye medier udfordrer vores måder at toenke og forstå loering på samt de nye muligheder for at designe for loering, som de giver.

\section{Litteratur}

Askehave, I., Linnemann Prehn, H., Pedersen, J. \& Thorsø Pedersen, M. (red.). (n.d.). PBL - Problem Baseret Loering. Aalborg universitet Rektorsekretariatet. Retrieved from http://www.aau.dk/digitalAssets/148/148026_pbl-aalborgmodellen_dk.pdf

Bygholm, A. \& Nyvang, T. (2013). IKT-støttet læring og kvalitet - erfaringer fra uddannelserne i Humanistisk Informatik på Aalborg Universitet. I Y. Nordkvelle, 
T. Fossland \& G. Netteland (red..): Kvalitet i fleksibel høyere utdanning - nordiske perspektiver. Akademika Forlag.

Cuesta, M., Eklund, M., Rydin, I. \& Witt, A.-K. (2016). Using Facebook as a co-learning community in higher education. Learning, Media and Technology, 41(1), 55-72. http://doi.org/10.1080/17439884.2015.1064952

Dirckinck-Holmfeld, L. (2016). Networked learning and problem and project based learning - how they complement each other. I S. Cranmer, N. Bonderup-Dohn, M. de Laat, T. Ryberg \& J.-A. Sime (red.): Proceedings of the 10th International Conference on Networked Learning 2016, 193-199. Lancaster University.

Heilesen, S. \& Davidsen, S. (2016). Projektarbejde og akademisk IT-skoling.Laring og Medier (LOM), 9(15). Retrieved from http://ojs.statsbiblioteket.dk/index.php/lom/article/view/23106

Holgaard, J. E., Ryberg, T., Stegeager, N., Stentoft, D. \& Thomassen, A. O. (2014). PBL: Problembaseret laering og projektarbejde ved de videregående uddannelser. Frederiksberg: Samfundslitteratur.

Hommes, J., Rienties, B., Grave, W. de, Bos, G., Schuwirth, L. \& Scherpbier, A. (2012). Visualising the invisible: a network approach to reveal the informal social side of student learning. Advances in Health Sciences Education, 17(5), 743-757. http://doi.org/10.1007/s10459-012-9349-0

Illeris, K. (1976). Problemorientering og deltagerstyring: oplaeg til en alternativ didaktik (2nd ed.). København: Munksgaard.

Konnerup, U. \& Dirckinck-Holmfeld, L. (2016). Future workshop as a didactic framework for doing problem based learning. I Design for learning 2016 designing new learning ecologies (Vol. 5). Copenhagen.

Madge, C., Meek, J., Wellens, J. \& Hooley, T. (2009). Facebook, social integration and informal learning at university: "It is more for socialising and talking to friends about work than for actually doing work." Learning, Media and Technology, 34(2), 141-155. http://doi.org/10.1080/17439880902923606

Petrovic, N., Jeremic, V., Cirovic, M., Radojicic, Z. \& Milenkovic, N. (2013). Facebook vs. Moodle: What do students really think. I International Conference on Information Communication Technologies in Education, 413-421.

Rienecker, L., Von Müllen, R., Stray Jørgensen, P. \& Holten Ingerslev, G. (2013). Aktiviteter i og uden for undervisningen. I L. Rienecker, P. Stray Jørgensen, J. Dolin \& G. Holten Ingerslev (red.): Universitetspaedagogik. Frederiksberg: Samfundslitteratur, 229-250.

Rienties, B., Carbonell, K. B., Alcott, P., \& Willis, T. (2012). Understanding emerging knowledge spillovers in small-group learning settings: The role of project-based learning, friendship and work-relations. I Proceedings of 8th International Conference on Networked Learning, 533-540.

Rongbutsri, N., Khalid, M. S. \& Ryberg, T. (2011). ICT support for students' collaboration in problem and project based learning. I J. Davies, E. de Graaf \& A. 
Kolmos (red.): PBL Across The Disciplines. Aalborg: Aalborg Universitetsforlag, 351-363.

Ryberg, T., Davidsen, J. \& Hodgson, V. (2016). Problem and project based learning in mixed spaces: Nomads and artisans. I Networked Learning 2016 Conference Proceedings. Lancaster University.

Ryberg, T. \& Wentzer, H. (2011). Erfaringer med e-porteføljer og personlige læringsmiljøer. Dansk Universitetspaedagogisk Tidsskrift, 11.

Salmon, G. (2002). E-tivities: the key to active online learning. London, Sterling, VA: Kogan Page Stylus Pub.

Thoms, B. P. (2016). Online learning community software to support success in project teams. Global Journal of Information Technology, 5(2), 71. http://doi.org/10.18844/gjit.v5i2.197

Thomsen, D. L., Sørensen, M. T. \& Ryberg, T. (2016). Where have all the students gone? They are all on Facebook Now. I S. Cranmer, N. Bonderup-Dohn, M. de Laat, T. Ryberg \& J.-A. Sime (red.): Proceedings of the 10th International Conference on Networked Learning 2016. Lancaster University.

Wenger, E. (1998). Communities of practice: Learning, meaning, and identity. Cambridge: Cambridge University Press. 